\title{
Recurrent temporomandibular joint dislocation secondary to epilepsy
}

\author{
Ryohei Ono 지 , Izumi Kitagawa
}

Department of General Internal Medicine, Shonan Kamakura General Hospital, Kamakura, Japan

\section{Correspondence to} Dr Ryohei Ono; ryohei_ono_0820@yahoo.co.jp

Accepted 12 October 2020

\section{DESCRIPTION}

An 84-year-old incommunicable woman with a history of left cerebral haemorrhage presented with five episodes of temporomandibular joint (TMJ) dislocation in 1 month. Each dislocation was associated with an ocular deviation, which resolved spontaneously within 1 hour and manual reductions were attempted. A physical examination revealed strong rigidity and anterior dislocation of the bilateral TMJ (figure 1A) and conjugate ocular deviation towards the left (figure 1B). A head CT scan showed no brain mass or bleeding. Electroencephalography was performed during the attack and the signals showed epileptiform discharges (figure 2). Diazepam reduced her rigidity (figure 1C) and conjugate ocular deviation. The patient was started on levetiracetam and these symptoms resolved.

Diseases including Parkinson's disease, Huntington's disease, muscular dystrophy and seizure disorders that affect muscular tone or coordination can result in TMJ dislocation. ${ }^{1}$ However, dislocation of the TMJ due to seizures has rarely been reported. ${ }^{23}$ Another case reported that epileptic seizures could cause shoulder dislocations other than TMJ dislocations. ${ }^{4}$ Our case captured the epileptic attack and the association between dislocation of the TMJ and epilepsy was confirmed. It is important for generalists to consider the possibility of seizure if they notice recurrent dislocation of the TMJ in incommunicable patients. Both control of the seizure and skills of manual reduction are needed if TMJ dislocation occurs secondary to epilepsy.

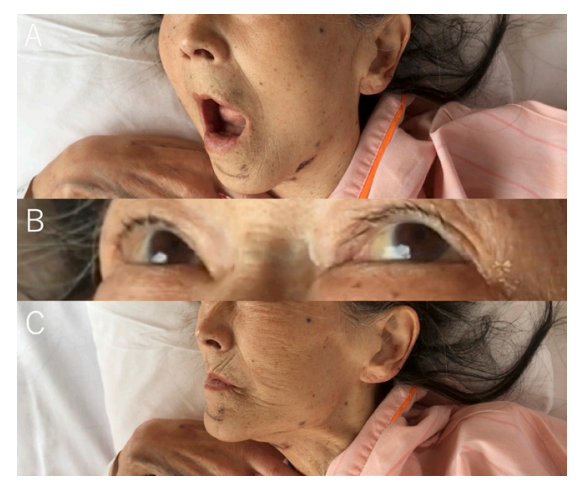

Figure 1 (A) Temporomandibular joint dislocations. (B) Conjugate ocular deviation towards the left. (C) Recovered temporomandibular joint dislocations after the administration of diazepam.

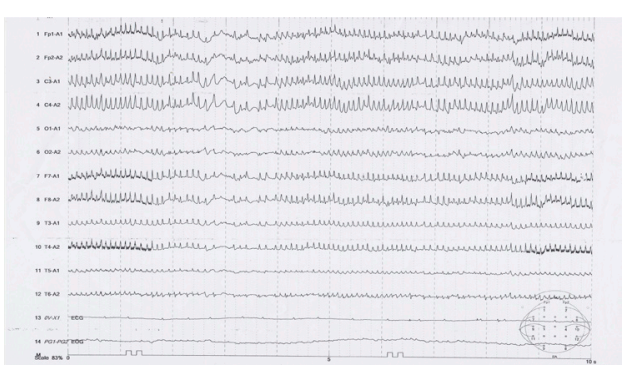

Figure 2 An electroencephalography during the attack showing epileptiform discharges.

\section{Learning points}

Dislocation of temporomandibular joint (TMJ) could occur due to epilepsy.

- It is important to consider the possibility of seizure if they notice recurrent dislocation of TMJ in incommunicable patients.

- Both control of the seizure and skills of manual reduction are needed if TMJ dislocation occurs secondary to epilepsy.

Contributors RO contributed to patient management, conception and design of case report; acquisition, analysis and interpretation of data and drafting the article. IK contributed to patient management and revising the article.

Funding The authors have not declared a specific grant for this research from any funding agency in the public, commercial or not-for-profit sectors.

Competing interests None declared.

Patient consent for publication Next of kin consent obtained. Provenance and peer review Not commissioned; externally peer reviewed.

\section{ORCID iD}

Ryohei Ono http://orcid.org/0000-0002-4875-7470

\section{REFERENCES}

1 Matthews NS. Chapter 3, Acute TMJ Dislocation and Technique of Manual Reduction. In: Dislocation of the temporomandibular joint: a guide to diagnosis and management. 1st ed. Springer International Publishing, c2018: p. 42.

2 Behere PB, Marmarde A, Singam A. Dislocation of the unilateral temporomandibular joint a very rare presentation of epilepsy. Indian J Psychol Med 2010;32:59-60.

3 Rakotomavo F, Raotoson H, Rasolonjatovo TY, et al. Temporomandibular joint dislocation during status epilepticus. Oxf Med Case Reports 2016;2016:omw055.

4 Mofidi M, Kianmehr N, Farsi D, et al. An unusual case of bilateral anterior shoulder and mandible dislocations. Am J Emerg Med 2010;28:745.e1-745.e2. 
Copyright 2020 BMJ Publishing Group. All rights reserved. For permission to reuse any of this content visit https://www.bmj.com/company/products-services/rights-and-licensing/permissions/

BMJ Case Report Fellows may re-use this article for personal use and teaching without any further permission.

Become a Fellow of BMJ Case Reports today and you can:

- Submit as many cases as you like

Enjoy fast sympathetic peer review and rapid publication of accepted articles

Access all the published articles

Re-use any of the published material for personal use and teaching without further permission

Customer Service

If you have any further queries about your subscription, please contact our customer services team on +44 (0) 2071111105 or via email at support@bmj.com.

Visit casereports.bmj.com for more articles like this and to become a Fellow 